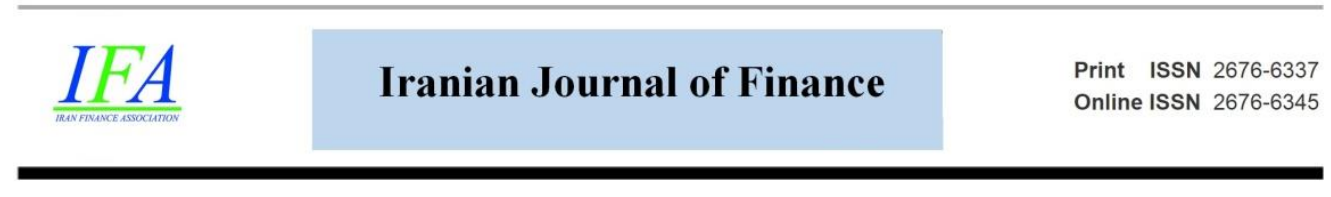

\title{
Model of Sustainable Tax Development Practices under Information Environment by Total Interpretive/Structural Model (TISM)
}

\section{Hasan Abedi}

PhD Candidate, Department of Accounting, Shahrood Branch, Islamic Azad University, Shahrood, Iran. (Email: h.abedi.134@gmail.com)

\section{Mohammad Reza Abdoli*}

*Corresponding Author, Associate Prof., Department of Accounting, Shahrood Branch, Islamic Azad University, Shahrood, Iran. (Email: mrab830@yahoo.com)

\section{Farhad Dehdar}

Assistante Prof., Department of Accounting, Shahrood Branch, Islamic Azad University, Shahrood, Iran. (Email: f.dehdar1970@yahoo.com)

Document Type: Original Article

Received: 2020/10/03

Accepted: 2020/12/19
2020, Vol. 4, No. 4. 1-27

Published: 2020/12/27

\section{Abstract}

The dynamics of corporate information environments are seen as a basis for managerial decision-making such as sustainable tax development, which can reduce agency costs and promote market-level information symmetry across regulatory bodies. The purpose of this research is presenting a Model of Sustainable Tax Development Functions under the Information Environment of Tehran Stock Exchange Companies. In this research-based on qualitative and quantitative methodology, Initially, 13 tax professionals who were also active at the university level, Participated in the Meta-synthesis and the Delphi section to validate the research components and indicators among the 11 approved studies, Delphi analysis used to identify the theoretical adequacy of the component and the set of indices. In the quantitative section, $28 \mathrm{CEO}$ of the stock exchange companies who were selected through an available sampling method selected randomly and used matrix questionnaires to stratify the identified indices in a range of the most influential indices. To the least effective indicators. The results in qualitative Analysis indicate the existence of three main components in the form of the final indicators based on theoretical adequacy and in the quantitative section, it was found that the indicators, greater dynamics of the value of the company based on tax transparency $(\mathrm{C} 1)$ 
as an indicator of external information environment functions and increased The level of disclosure of economic performance in line with the GRI standard (C9) and the strategic balance between tax minimization and corporate value (C10) as an indicator of the component of internal information environment functions most strongly as a consequence of sustainable tax development under corporate information environment conditions for stock companies. Tehran Stock Exchange. These results show that the development of sustainable tax functions under corporate information environment conditions can also help to improve the effectiveness of corporate internal operations, regardless of the positive effects on the competitive and market levels.

Keywords: Sustainable Tax Development Functions, Information Environment Companies, Total Interpretive/Structural.

DOI: 10.30699/iif.2020.121429

Copyright: author(s)
Publisher: Iran Finance Association

Type of License: Creative Commons License (CC-BY 4.0)

\section{Introduction}

As the economic warfare between the developing and developed countries grew, taxes are doubly important for countries as income sources. Indeed, taxes have been particularly significant in recent years, especially in developing countries like ours, subject to foreign sanctions and economic infrastructure issues. Accordingly, it should be noted that achieving economic development requires the implementation of tax policies by the governments to reach macroeconomic goals, on the one hand, and tax stabilization on the stock markets where capital assets are purchased and sold, on the other hand. Stabilization in these markets can enhance the level of tax regulatory practices, and at the same time, be regarded as an important strategic tool among companies (Sadeghi, Ranjpour, Bagherzadeh, and Mousavi, 2015).

As mentioned earlier, tax development in the capital market can enhance the effective tax regulatory practices, leading companies to use taxes as a key driver in formulating their competitive strategies (Chen, Hepfer, Quinn \& Wilson, 2018). In this case, the agency theory based on which shareholders' lawyers are authorized for decision-making makes the predominant presupposition in the stock market that businesses are less inclined toward tax transparency and attempt to evade paying taxes in various ways. On the other hand, according to the contract theory, which established a clear relationship between managerial compensation (executive compensation) and recorded earnings, managers would have the incentives required to minimize their tax liability and payments due to opportunistic incentives, such as earnings management (Pourheidari, and Shafiei Hemmatabad, 2013). In other words, managers tend to lower their ETRs to pay less tax to make more profit by 
transferring the expenses of future periods to present periods and delaying revenue recognition. Notably, the strategies of minimizing effective tax rate $(\mathrm{ETR})^{1}$, e.g., tax avoidance may be discarded, or tax exemptions and incentives may expire, in the future, thereby raising agency expenses and, consequently, weakening the firm's competitive practices in the capital market. This can lead to increased ETR in a U-shaped trend. A rise in tax avoidance due to managers' opportunistic incentives may lead to reduced tax payments in the short term, though it can enhance the firm's ETR in the long run (Papadopoulou \& HristuVarsakelis, 2019).

One strategic approach in capital markets is to exploit tax capacity to ensure sustainable tax development under corporate information environment conditions. "Information environment," which refers to the extra-organizational information space where the company operates and always aims to boost transparency levels (Heidarzadeh Hanzaei and Barati, 2019), can boost financial stability in competitive markets. Since investors need prospective information to make decisions under the conditions of non-transparency to predict risk and firm's future returns, control the decision-making process under the conditions of a non-optimized (non-optimal) information environment, which raises the risks and lowers firm value. When investors are obliged to rely on management profit and sales projections (forecasting) due to a lack of access to firms' confidential information, focusing on the information environment can be of great importance. This is because it can increase tax stability practices at the macro level, on the one hand, facilitate Information symmetry in the stock market, on the other hand.

Under such circumstances, it is expected that boosting the information environment and establishing an analytical atmosphere in the market increases the market transparency and investors' awareness, and at the same time, direct corporate tax practices toward higher sustainability, thereby reducing the unsystematic risk of the firm by improving the stakeholders' decision-making process (Kafashpour Yazdi, Taftian and Moinuddin, 2019). Accordingly, the information environment has consequences for sustainable tax development, which is indeed a combination of strategies that balances the ETR in the long run and diminishes the tax risk that indicates corporate tax rates volatility and uncertainty in future tax payments (Guenther, Matsunaga \& Matsunaga, 201;

\footnotetext{
${ }^{1}$ The effective tax rate is different from the legal tax rate, due to the use of tax exemptions or tax avoidance strategies. The legal tax rate in Iran is equal to $25 \%$, according to the Direct Taxes Law of 22/07/2015 and previous amendments (Golestani et al., 2014).
} 
Hutchens \& Rego, 2015). In other words, the establishment of an information environment by controlling the ETR minimization can lead to more consistent tax forecasting by the firm in the competitive market, as well as tax stabilization and reducing the relevant risks. Given the significance of the contributions of tax revenues in the country's budget planning and progressing to initiatives such as the Comprehensive Tax Plan (Initiative), this study can help achieve higher consistency in conceptual layers and identify the opportunistic implications of tax sustainability. It can also reduce costs and increase corporate cash flows and, at the same time, examine income tax returns of such leading firms in the market without tax audits due to a dynamic and transparent information environment under Article 97 of the Direct Taxes Act and Amendment No 07/22/2015 under trust-based transparency. Thus, this study aims to present a sustainable tax development practice model under the conditions of the information environment of the companies listed under the Tehran Stock Exchange.

The paper is structured as follows, Section II is accompanied by an attempt to present the theoretical aspects of the research to boost theoretical support and analysis in the "Conclusion" section. Section III presents the research methodology by relying on the procedure and target population. Section IV discusses the experimental findings based on three analytical approaches: meta-synthesis, Delphi, and interpretive structural. Section V discusses and analyzes the results based on the experimental findings and theoretical support.

\section{Literature Review}

\section{Sustainable tax development}

Sustainability is a multidimensional concept as it pursues solutions among conflicting criteria. Numerous composite indicators have been developed to assess sustainability in various areas of mankind do- ing: innovation, development, economy, eco-system, industry, energy, cities, environment or society and wellbeing. As composite indicators can describe and synthesize multidimensional concepts in different domains, they are being used more and more frequently for macroeconomic evaluation of public policies (DiazBalteiro et al, 2017).

In addition to financing the government, taxes are also important in other ways. Taxes are one of the government's economic instruments to interfere with the market when necessary. It is a tool to fund the government to accomplish other goals of human societies. This is because, with any political system, 
governments pursue three primary goals: economic stability, equal income distribution, and the optimal resource allocation. Taxes influence the community's distribution conditions (distributive structures), on the one side, given the tax incidence, and have allocative consequences (resource allocation consequences) by shifting resources from one market to another, on the other (Sadeghi, Beheshti, Ranjpour, and Ebrahimi, 2018).

Thus, tax and economic experts are actively searching for sustainable tax development to increase the level of development-based practices. These practices lead to dynamic competitiveness due to techniques for disclosing tax facts (information) in the markets, such as the capital market (Hogsden, 2018). Sustainable taxation is seen as a strategic feature at the stock market level and will help enhance economic dynamism if the level of interactive government approaches increases. In effect, tax sustainability is a policy in which pre-tax earnings shift little (Dyreng, Hanlon \& Maydew, 2014) and focuses on preserving the effects of tax avoidance over time. Tax stability ensures the stability of earnings after tax and the opportunity to foresee potential cash rewards that will generate income for the business in the long term (Vaez, Daresh, Basirat, and Kaaba Amir, 2018).

Minimizing the effective tax rate often adds to expenses such as tax fines and increased business funding charges, decreasing revenue profitability, the uncertainty of potential tax payments, and growing tax risk (Hutchens \& Rego, 2015). On the other hand, tax avoidance is characterized by various tax avoidance practices, from lucrative tax avoidance (such as tax relief government bonds) to daring tactics that threaten the company (Dyreng, Hanlon \& Maydew, 2014). The introduction of tax avoidance practices to reduce the effective tax rate in the short-term affects tax sustainability (McGuire, Neuman \& Omer, 2013). Dyreng, Hanlon \& Maydew (2019) note that tax sustainability means long-term tax avoidance. Tax survival is not based on tax minimization, but on preserving the effects of tax avoidance, independent of tax minimization over time.

On the other hand, tax avoidance focused on tax avoidance focuses on the sum of tax obligations over a period of time and fails to sustain tax avoidance activities and hold tax rates down in the future (David, Wilson, \& Kaishu, 2019). KPMG Accounting Institute, one of four major firms, announced in 2007 that tax sustainability is a long-term target for corporations. This is because, for financial economists, sudden increases in tax rates are a symbol of bad governance.

2. Sustainable tax development practices under the conditions of the 


\section{corporate information environment}

According to agency philosophy, management incentives are mechanisms to resolve the conflict of interest between managers and owners and an opportunity to balance the parties' interests. In these situations, one of the management benefits based on the argument that shareholder capital is maximized is eliminating tax costs, which typically happens in businesses with a lack of information-based productivity. Accordingly, Gallemore \& Labro (2015); David, Wilson, and Kaishu (2019), and Hamilton \& Stekelberg (2017) claim that, in the absence of an efficient knowledge environment, managers are using tax avoidance techniques and reducing effective tax rates for two reasons, namely in the interests of shareholders and encouraged to minimize tax liabilities (Phillips, 2003) for their own gain and the benefit of shareholders (Desai \& Dharmapala, 2009).

Tax avoidance can also be used as a catalyst in the absence of a clear corporate knowledge setting, illustrating the shortcomings of agency theory. The company's information environment contains financial statements and public and proprietary information accessible to the stock market by mandatory or voluntary disclosure by the company (Leece \& White, 2017). The business environment is a knowledge domain beyond the organization in which the company works, and it often tries to explain and reduce its complexity (Fakhari and Rezaei Pithanoui, 2017). Indeed, considering the anticipated viability of the acquisition prospects of the business, it can be understood that accounting information decreases the information asymmetry between private information managers and external resource providers (Akerlof, 1970).

\section{Research background}

Mgammal (2019) published a study entitled "Investigating the Influence of Corporate Tax Preparation on the Disclosure of Corporate Tax Results," which found that tax planning as a strategy in line with tax uniformity policies has a favorable and important impact on the disclosure of corporate tax performance. In particular, these findings confirm the presence of behavioral and functional coherence in corporate tax disclosure and identify it as a factor in businesses' success in raising financial capital due to investor trust. Chen, Hipfer, Quinn, and Wilson (2018) published a report entitled "Analysis of the direction of tax incentives under information asymmetry," which found that tax incentives with two purposes of profitability and quality to improve investment opportunities under the control of information asymmetry have reciprocal practices. Jenter, Matsunaga, and Matsunaga (2017) published a study entitled Exploring the 
Effects of an Effective Tax Rate on Tax Resilience and Corporate Risk. The findings found that the lower the effective tax rate, the more stable it is than, the higher the effective tax rate. There was also no substantial association between the effective tax rate and the tax risk. Sari et al. (2009) published a study entitled The Role of Internal Information Environment Efficiency in the Reduction of Corporate Tax Risk. Study results indicate that environmental risks raise the tax risk.

On the other hand, the findings of the study show the importance of environmental factors, the assessment method, financial statements, and internal tax risk control. Vaez et al. (2016) published a study entitled "Assessing the company's financial stability and potential tax risk with a focus on the form of ownership." The findings of this analysis have shown that businesses with higher effective tax rates have greater financial stability.

\section{Methodology}

Methodologically, it should be noted that this study is viewed as part of the result-based growth research because owing to the theoretical discrepancy with respect to the implications of sustainable tax creation, this research aims to focus on research performed through Meta-synthesis. Under the information system's constraints, philosophical and analytical coherence on this topic at the stock market level. Based on the intent of the analysis, it is descriptive and is dependent on the form of results. It's. This study uses a systematic Metasynthesis, a Delphi, and an interpretive structural analysis, both of which will be carried out according to the project's needs and phases with the unique involvement of the target members.

The statistical population, as defined, consists of two classes of individuals, each of whom was chosen according to the method of sampling. In the qualitative part of this analysis, 13 tax specialists involved at the university level participated in the qualitative portion as representatives of the target population, identified as the target group using quantitative sampling based on the gatekeeper knowledge process. These individuals were distinguished by an awareness of the topics relevant to the study's context and purpose, which played an important role in defining the trends and subsequent roles of sustainable tax growth. In the quantitative portion, 28 stock exchange firms' managers were chosen non-randomly through the accessible sampling process. A significant number of participants are not needed to generalize the findings to evaluate the sample size in the quantitative method, a detailed interpretive structural study. This approach focuses on analyzing complex structures at 
particular levels and must be carried out by researchers based on specific qualifications, such as skill or competence. The number of members of the target population is limited and minimal.

\section{Experimental findings}

\section{Qualitative part findings}

The first internal search engines, such as journals licensed by the Ministry of Science, were used to conduct a Meta-synthesis for research topics and databases. In other words, research relevant to the research purpose has been defined to identify similar articles and researches and use the databases and references listed above.

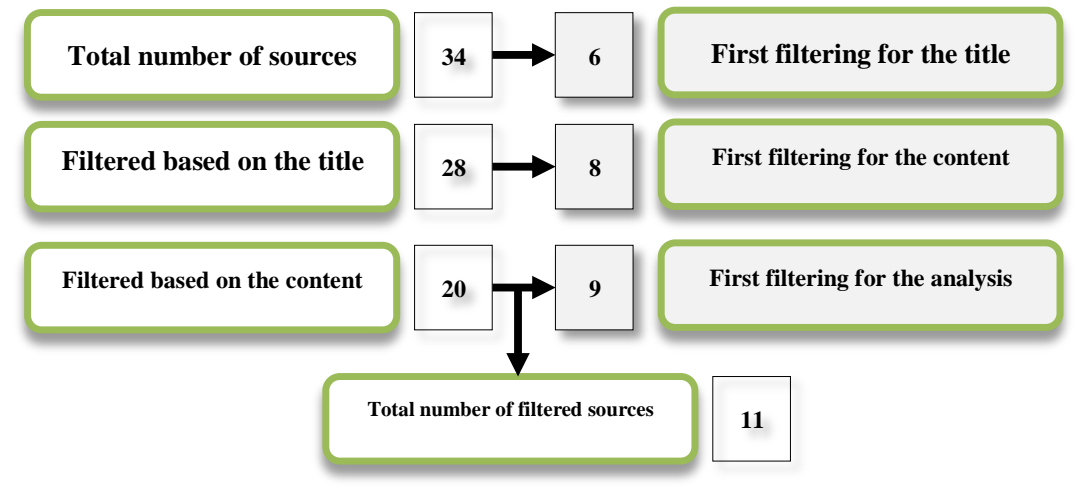

Figure 1: The process of defining the appropriate studies and articles to identify components and indices

After screening the study results, it was decided that 11 of the 34 inquiries analyzed had been accepted to evaluate the components and metrics relevant to the implications of improving tax sustainability in the context of a Metasynthesis method called a Critical Appraisal Skills Program (CASP), under the circumstances of the communication environment of businesses. Based on this method, 11 pieces of research accepted using 10 Essential Assessment System Basic Criteria, including Study Goals, Research System Rationale, Test Architecture, Sampling, Data Collection, Reflectivity, Measurement Precision, Theoretical and Consistent Interpretation of Results, and Research Importance, with the support of 13-panel members, are re-engineered to create a more cohesive understanding of the findings. 
Table 1. Critical evaluation of the studies identified

\begin{tabular}{|c|c|c|c|c|c|c|c|c|c|c|c|c|c|c|}
\hline \multicolumn{5}{|l|}{ Place } & \multicolumn{5}{|c|}{ Internal research } & \multicolumn{5}{|c|}{ External research } \\
\hline & 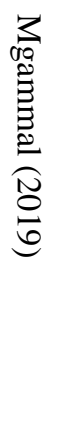 & $\begin{array}{l}\sum_{0} \\
\stackrel{\Xi}{0} \\
\underset{0}{0} \\
0 \\
0\end{array}$ & 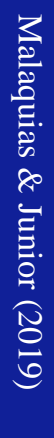 & 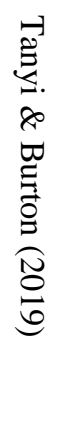 & 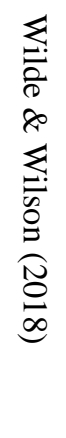 & 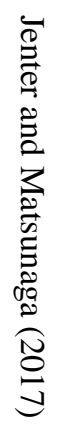 & 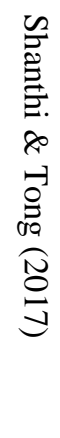 & 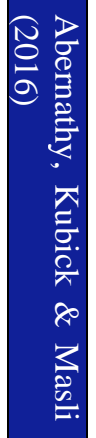 & 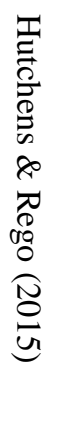 & 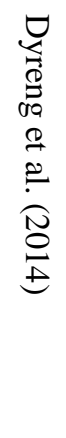 & 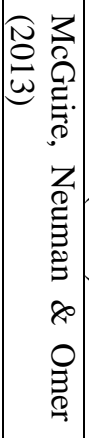 & 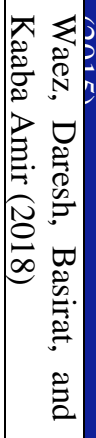 & 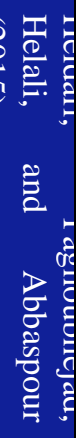 & 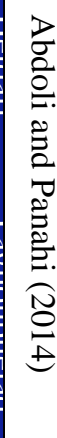 \\
\hline $\begin{array}{l}\text { Purpose of the } \\
\text { research }\end{array}$ & 3 & 4 & 2 & 4 & 4 & 4 & 4 & 2 & 4 & 4 & 4 & 4 & 3 & 4 \\
\hline $\begin{array}{l}\text { The logic of } \\
\text { the research } \\
\text { method }\end{array}$ & 4 & 3 & 2 & 3 & 4 & 4 & 3 & 3 & 3 & 4 & 3 & 3 & 3 & 3 \\
\hline $\begin{array}{l}\text { Research } \\
\text { design }\end{array}$ & 4 & 5 & 2 & 4 & 3 & 4 & 3 & 3 & 3 & 4 & 3 & 3 & 2 & 3 \\
\hline Sampling & 4 & 3 & 2 & 4 & 4 & 4 & 3 & 3 & 4 & 4 & 3 & 3 & 3 & 4 \\
\hline $\begin{array}{l}\text { How to collect } \\
\text { data }\end{array}$ & 4 & 4 & 1 & 4 & 3 & 4 & 3 & 2 & 4 & 3 & 3 & 4 & 3 & 3 \\
\hline $\begin{array}{l}\text { Generalized } \\
\text { Findings }\end{array}$ & 5 & 4 & 3 & 3 & 4 & 5 & 4 & 2 & 4 & 4 & 3 & 3 & 2 & 3 \\
\hline $\begin{array}{l}\text { Ethical } \\
\text { approaches }\end{array}$ & 4 & 4 & 3 & 4 & 3 & 4 & 4 & 3 & 4 & 4 & 4 & 3 & 3 & 4 \\
\hline $\begin{array}{l}\text { How statistical } \\
\text { analysis }\end{array}$ & 5 & 5 & 2 & 4 & 3 & 5 & 4 & 2 & 4 & 3 & 3 & 3 & 2 & 3 \\
\hline $\begin{array}{l}\text { Theoretical } \\
\text { capability }\end{array}$ & 4 & 4 & 2 & 4 & 3 & 5 & 4 & 3 & 3 & 4 & 4 & 4 & 2 & 2 \\
\hline $\begin{array}{l}\text { The value of } \\
\text { research }\end{array}$ & 4 & 5 & 2 & 4 & 3 & 4 & 4 & 2 & 3 & 4 & 4 & 5 & 3 & 3 \\
\hline Total & 41 & 41 & 21 & 38 & 34 & 39 & 36 & 25 & 38 & 34 & 34 & 35 & 26 & 32 \\
\hline
\end{tabular}

According to the Mode Index, in which the scores of the panel members were given based on their attendance and a scale of 1-5, it was calculated that out of the 14 studies reviewed in this section, three studies by Malakowis and Jr. (2019); Abransi, Kubik, and Masli (2016) and Heidari, Yaghoubnejad, Helali and Abbaspour (2015) were omitted from the analysis because they were below 30. According to the approved research and based on the Sterling 
process (2001), the production of tax sustainability is derived under the conditions of the firms' knowledge atmosphere dependent on the approved research. Based on this process, all components derived from the text of the accepted publications are placed in the column of the table, and the names of the accepted researchers are placed in the row of each table. Based on each researcher's use of the key components written in the table section, the " $\checkmark$ " symbol is introduced, the scores of each $\checkmark$ are added together in the subcriteria section. The scores above the average of the analysis are chosen as test components.

Table 2: Determining the main components of tax consequences under corporate information environment conditions

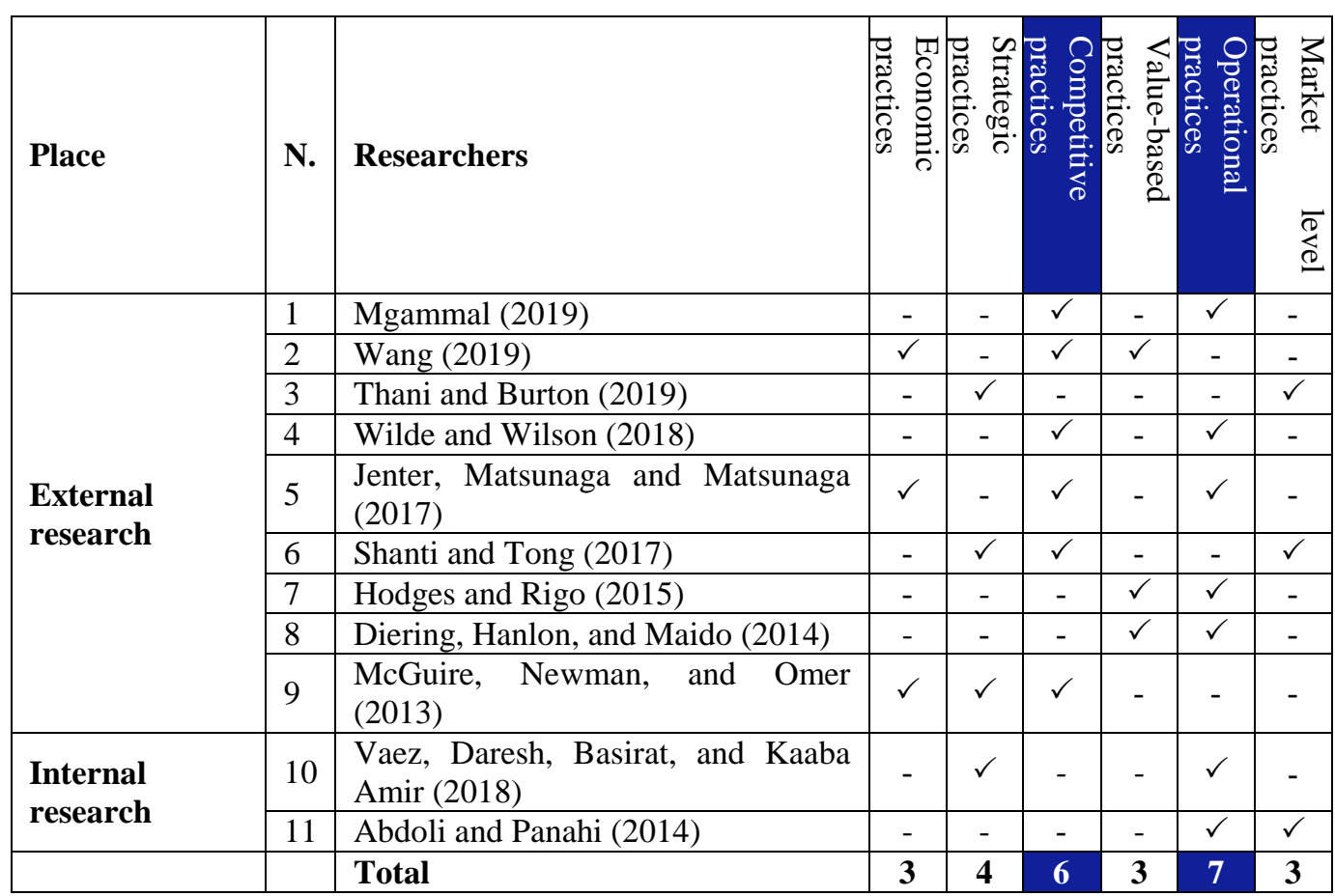

Of the six main components relevant to the growth of tax stability under the conditions of the corporate information environment, two main components of the strategic practices and the operational practices of sustainable tax development under the conditions of the information system of capital market firms have been chosen. Considering that 11 of the research in this section was examined based on all the components of the approved research and based on the frequency of the results obtained, the research that obtained more than half 
of the approved research was chosen as sub-components of the research. Table (3) displays the metrics used in validated testing for each of the specified components.

Table 3. The indices of tax consequences under corporate information environment conditions

\begin{tabular}{|c|c|c|c|c|c|c|c|c|}
\hline Component & Index & 7 & 6 & 5 & 4 & 3 & 2 & 1 \\
\hline \multirow{12}{*}{ 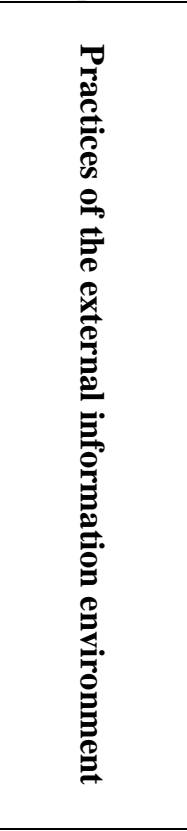 } & $\begin{array}{c}\text { Greater dynamics of company value based on tax } \\
\text { transparency }\end{array}$ & & & & & & & \\
\hline & $\begin{array}{l}\text { Protecting the rights of stakeholders in a } \\
\text { competitive environment }\end{array}$ & & & & & & & \\
\hline & Increase the decision-making power of stakeholders & & & & & & & \\
\hline & Improving stakeholder communication capabilities & & & & & & & \\
\hline & $\begin{array}{l}\text { Increase the level of trust in the company's tax } \\
\text { performance }\end{array}$ & & & & & & & \\
\hline & $\begin{array}{l}\text { Reduce the inherent risk of corporate tax strategies } \\
\text { in a competitive environment }\end{array}$ & & & & & & & \\
\hline & $\begin{array}{l}\text { No risk of transferring costs of future periods to the } \\
\text { current period }\end{array}$ & & & & & & & \\
\hline & Reduction of profit before tax & & & & & & & \\
\hline & Sustainability in profit after tax & & & & & & & \\
\hline & Ability to predict future cash flows & & & & & & & \\
\hline & Reduce tax risk & & & & & & & \\
\hline & $\begin{array}{l}\text { Persuasion of transparency and tax reporting of } \\
\text { stakeholders }\end{array}$ & & & & & & & \\
\hline \multirow{12}{*}{ 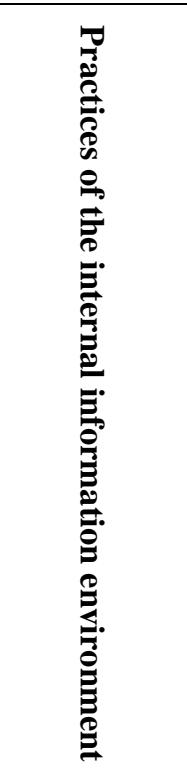 } & $\begin{array}{l}\text { Reduction of financial expenses due to non-payment } \\
\text { of taxes }\end{array}$ & & & & & & & \\
\hline & Use of bonuses and tax deductions & & & & & & & \\
\hline & Obtaining tax exemptions without legal violations & & & & & & & \\
\hline & $\begin{array}{l}\text { Increasing the level of disclosure of economic } \\
\text { performance in line with the GRI standard }\end{array}$ & & & & & & & \\
\hline & $\begin{array}{l}\text { The strategic fit between tax depreciation and } \\
\text { company value }\end{array}$ & & & & & & & \\
\hline & Tax rate uniformity & & & & & & & \\
\hline & $\begin{array}{c}\text { Proportionality of tax approaches in balancing } \\
\text { sustainable taxation with the company's information } \\
\text { environment }\end{array}$ & & & & & & & \\
\hline & Reduce audit costs & & & & & & & \\
\hline & $\begin{array}{l}\text { Disclosure of information content of sustainable tax } \\
\text { activities }\end{array}$ & & & & & & & \\
\hline & $\begin{array}{l}\text { Management effectiveness in controlling } \\
\text { unexpected changes in tax rates }\end{array}$ & & & & & & & \\
\hline & The dynamics of the company's business strategies & & & & & & & \\
\hline & Reduce financial constraints & & & & & & & \\
\hline
\end{tabular}


As shown in Table (3), the key components and indices of the tax consequences would be calculated in the businesses' knowledge set in the context of a 7-point Likert scale. This segment, focused on the Delphi review, attempts to assess the components' theoretical adequacy and tax implications under the business information set's circumstances. In this stage, consistency, validity, reliability tests, and Delphi analysis (in the analyzed section) are used. To validate the validity of the questionnaires, the material validity ratio (CVR) approach was used. All 13-panel members in the rating segment were asked to report their scores for each sub-component. As a result, as the CVR value is greater than 0.62 (minimum material validity ratio for ten-panel members), the testing components' content validity has been verified. In terms of reliability, as shown in the Delphi analysis section, the two parameters of the agreement's average and coefficient are used by the panel members in the qualitative section. According to the 7-point Likert scale (Delphi analysis tool), any variable that does not score the appropriate score is excluded and used based on reliability.

\section{Delphi Analysis}

In this section, the components arising from the hyper-combination study provided in Table (4) are analyzed to validate or exclude the testing components on experts' input (panel members) based on the two scales of the average and the agreement coefficient. The findings of the Delphi review are seen in Table (4).

Table 4. Analysis of the meta-synthesis results in first-round Delphi

\begin{tabular}{|c|c|c|c|c|c|c|}
\hline $\begin{array}{c}\text { Compone } \\
\text { nt }\end{array}$ & $\begin{array}{c}\text { Concordan } \\
\text { ce }\end{array}$ & $\begin{array}{c}\text { Approv } \\
\text { ed/Reje } \\
\text { cted }\end{array}$ & Indices & $\underset{\mathbf{n}}{\text { Mea }}$ & $\begin{array}{c}\text { Coefficie } \\
\text { nt of } \\
\text { concorda } \\
\text { nce }\end{array}$ & $\begin{array}{c}\text { Approved } / \text { Re } \\
\text { jected }\end{array}$ \\
\hline \multirow{5}{*}{ 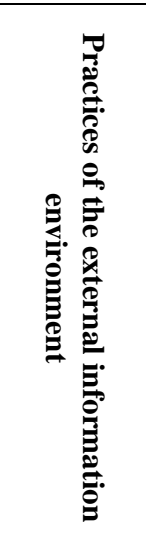 } & \multirow{5}{*}{0.88} & \multirow{5}{*}{$\begin{array}{c}\text { Approve } \\
\text { d }\end{array}$} & $\begin{array}{l}\text { Greater dynamics of } \\
\text { company value based on } \\
\text { tax transparency }\end{array}$ & 5.20 & 0.65 & Approved \\
\hline & & & $\begin{array}{l}\text { Protecting the rights of } \\
\text { stakeholders in a } \\
\text { competitive environment }\end{array}$ & 4.55 & 0.45 & \multirow{2}{*}{ Integrated } \\
\hline & & & $\begin{array}{l}\text { Increase the decision- } \\
\text { making power of } \\
\text { stakeholders }\end{array}$ & 5 & 0.50 & \\
\hline & & & $\begin{array}{l}\text { Improving stakeholder } \\
\text { communication } \\
\text { capabilities }\end{array}$ & 4 & 0.40 & Rejected \\
\hline & & & $\begin{array}{l}\text { Increase the level of trust } \\
\text { in the company's tax } \\
\text { performance }\end{array}$ & 4.90 & 0.48 & Integrated \\
\hline
\end{tabular}




\begin{tabular}{|c|c|c|c|c|c|c|}
\hline & & & $\begin{array}{l}\text { Reduce the inherent risk } \\
\text { of corporate tax } \\
\text { strategies in a } \\
\text { competitive environment }\end{array}$ & 4.98 & 0.50 & Integrated \\
\hline & & & $\begin{array}{l}\text { No risk of transferring } \\
\text { costs of future periods to } \\
\text { the current period }\end{array}$ & 5.10 & 0.55 & \\
\hline & & & $\begin{array}{lll}\begin{array}{l}\text { Reduction } \\
\text { before tax }\end{array} & \text { of profit } \\
\end{array}$ & 5.20 & 0.65 & Approved \\
\hline & & & $\begin{array}{l}\text { Sustainability in profit } \\
\text { after tax }\end{array}$ & 6 & 0.90 & Approved \\
\hline & & & $\begin{array}{l}\text { Ability to predict future } \\
\text { cash flows }\end{array}$ & 5.50 & 0.80 & Approved \\
\hline & & & Reduce tax risk & 5 & 0.50 & Integrated \\
\hline & & & $\begin{array}{l}\text { Persuasion of } \\
\text { transparency and tax } \\
\text { reporting of stakeholders }\end{array}$ & 5 & 0.50 & Integrated \\
\hline \multirow{12}{*}{ 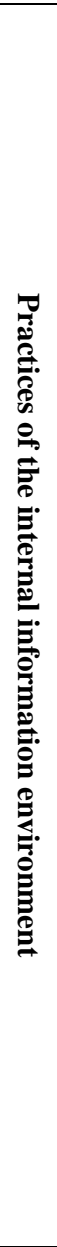 } & \multirow{12}{*}{0.90} & \multirow{12}{*}{$\begin{array}{l}\text { Approve } \\
\mathrm{d}\end{array}$} & $\begin{array}{l}\text { Reduce financial costs } \\
\text { due to the timely } \\
\text { payment of taxes }\end{array}$ & 4.98 & 0.50 & \multirow{3}{*}{ Integrated } \\
\hline & & & $\begin{array}{l}\text { Use of bonuses and tax } \\
\text { deductions }\end{array}$ & 5.10 & 0.55 & \\
\hline & & & $\begin{array}{l}\text { Obtaining tax } \\
\text { exemptions without legal } \\
\text { violations }\end{array}$ & 4.98 & 0.50 & \\
\hline & & & $\begin{array}{l}\text { Increasing the level of } \\
\text { disclosure of economic } \\
\text { performance in line with } \\
\text { the GRI standard }\end{array}$ & 5.10 & 0.55 & Approved \\
\hline & & & $\begin{array}{l}\text { The strategic fit between } \\
\text { tax depreciation and } \\
\text { company value }\end{array}$ & 5.20 & 0.65 & Approved \\
\hline & & & Tax rate uniformity & 5.20 & 0.65 & Approved \\
\hline & & & $\begin{array}{l}\text { Proportionality of tax } \\
\text { approaches in balancing } \\
\text { sustainable taxation with } \\
\text { the company's } \\
\text { information environment }\end{array}$ & 3 & 0.25 & Rejected \\
\hline & & & Reduce audit costs & 5.10 & 0.55 & Approved \\
\hline & & & $\begin{array}{l}\text { Disclosure of } \\
\text { information content of } \\
\text { sustainable tax activities }\end{array}$ & 3.50 & 0.30 & Rejected \\
\hline & & & $\begin{array}{l}\text { Management } \\
\text { effectiveness in } \\
\text { controlling unexpected } \\
\text { changes in tax rates }\end{array}$ & 5.20 & 0.65 & Approved \\
\hline & & & $\begin{array}{l}\begin{array}{l}\text { The dynamics of the } \\
\text { company's } \\
\text { strategies }\end{array} \\
\text { business }\end{array}$ & 5.20 & 0.65 & Approved \\
\hline & & & $\begin{array}{ll}\begin{array}{l}\text { Reduce } \\
\text { constraints }\end{array} & \text { financial } \\
\end{array}$ & 6 & 0.90 & Approved \\
\hline
\end{tabular}


Based on the two parameters of average and coefficient of agreement in the checklist of 7 alternatives, and according to the directions, the coefficient of the agreement must be below the norm of 0.5 to be accepted and the average of 5 points in that norm, as there are seven alternatives, all components can be specified. The key analysis was accepted. The following three claims were omitted because they had obtained less than 0,5 on the agreement coefficient and had an average of less than 5, and 10 measures were combined based on the definition and the coefficients obtained and formed an index. Table (5) displays the combined indices, and Table (6) displays the removed indices with the key components attached to both of them.

Table 5. First-round Delphi's integrated indices

\begin{tabular}{|c|c|c|}
\hline Integrated indices & New concept created & Components \\
\hline $\begin{array}{l}\text { Protecting the rights of stakeholders in a } \\
\text { competitive environment }\end{array}$ & \multirow{2}{*}{$\begin{array}{c}\text { Increasing the level of } \\
\text { stakeholder decision-making } \\
\text { values }\end{array}$} & \multirow{7}{*}{$\begin{array}{l}\text { Competitive } \\
\text { level }\end{array}$} \\
\hline $\begin{array}{l}\text { Increase the decision-making power of } \\
\text { stakeholders }\end{array}$ & & \\
\hline $\begin{array}{l}\text { Increase the level of trust in the } \\
\text { company's tax performance }\end{array}$ & \multirow{2}{*}{$\begin{array}{l}\text { Promote trust by convincing } \\
\text { sustainable tax reporting }\end{array}$} & \\
\hline $\begin{array}{l}\text { Persuasion of transparency and tax } \\
\text { reporting of stakeholders }\end{array}$ & & \\
\hline $\begin{array}{c}\text { Reduce the inherent risk of corporate } \\
\text { tax strategies in a competitive } \\
\text { environment }\end{array}$ & \multirow{3}{*}{$\begin{array}{l}\text { Reduce institutional tax risk in the } \\
\text { company }\end{array}$} & \\
\hline $\begin{array}{l}\text { No risk of transferring costs of future } \\
\text { periods to the current period }\end{array}$ & & \\
\hline Reduce tax risk & & \\
\hline $\begin{array}{l}\text { Reduce financial costs due to the timely } \\
\text { payment of taxes }\end{array}$ & \multirow{3}{*}{$\begin{array}{l}\text { Improving the level of tax } \\
\text { exemptions and reducing } \\
\text { financial costs }\end{array}$} & \multirow{3}{*}{$\begin{array}{l}\text { Operational } \\
\text { level }\end{array}$} \\
\hline Use of bonuses and tax deductions & & \\
\hline $\begin{array}{l}\text { Obtaining tax exemptions without legal } \\
\text { violations }\end{array}$ & & \\
\hline
\end{tabular}

Table 6. First-round Delphi's removed and integrated indices

\begin{tabular}{|c|c|}
\hline Removed indices & $\begin{array}{c}\text { Corresponding } \\
\text { components }\end{array}$ \\
\hline $\begin{array}{c}\text { Improving stakeholder communication capabilities } \\
\text { Competitive level } \\
\text { company's information environment } \\
\text { Increase the level of trust in the company's tax performance }\end{array}$ & Operational level \\
\hline
\end{tabular}


Due to recognizing the combined and removed indicators to achieve statistical adequacy, the second round of Delphi analysis is carried out in conjunction with Table (7).

Table 7: Second-round Delphi analysis of the meta-synthesis results

\begin{tabular}{|c|c|c|c|c|}
\hline Component & Index & Mean & $\begin{array}{c}\text { Coefficient } \\
\text { of } \\
\text { concordance }\end{array}$ & Approved/Rejected \\
\hline \multirow{7}{*}{$\begin{array}{l}\text { Practices of the } \\
\text { external } \\
\text { information } \\
\text { environment }\end{array}$} & $\begin{array}{l}\text { Greater dynamics of } \\
\text { company value based on } \\
\text { tax transparency }\end{array}$ & 5.25 & 0.70 & Approved \\
\hline & $\begin{array}{ll}\begin{array}{l}\text { Increasing the level of } \\
\text { stakeholder } \\
\text { making values }\end{array} & \begin{array}{l}\text { decision- } \\
\text { - }\end{array}\end{array}$ & 5.20 & 0.65 & Approved \\
\hline & $\begin{array}{l}\text { Promote trust by } \\
\text { convincing sustainable tax } \\
\text { reporting }\end{array}$ & 5.15 & 0.53 & Approved \\
\hline & $\begin{array}{l}\text { Reduce institutional tax } \\
\text { risk in the company }\end{array}$ & 5.10 & 0.55 & Approved \\
\hline & $\begin{array}{l}\text { Reduction of profit before } \\
\text { tax }\end{array}$ & 5.20 & 0.65 & Approved \\
\hline & $\begin{array}{l}\text { Sustainability in profit } \\
\text { after tax }\end{array}$ & 6.10 & 0.92 & Approved \\
\hline & $\begin{array}{l}\text { Ability to predict future } \\
\text { cash flows }\end{array}$ & 6 & 0.90 & Approved \\
\hline \multirow{8}{*}{$\begin{array}{l}\text { Practices of the } \\
\text { internal } \\
\text { information } \\
\text { environment }\end{array}$} & $\begin{array}{l}\text { Improving the level of tax } \\
\text { exemptions and reducing } \\
\text { financial costs }\end{array}$ & 5.10 & 0.55 & Approved \\
\hline & $\begin{array}{l}\text { Increasing the level of } \\
\text { disclosure of economic } \\
\text { performance in line with } \\
\text { the GRI standard }\end{array}$ & 5.20 & 0.65 & Approved \\
\hline & $\begin{array}{l}\text { The strategic fit between } \\
\text { tax depreciation and } \\
\text { company value }\end{array}$ & 5.50 & 0.85 & Approved \\
\hline & Tax rate uniformity & 6 & 0.90 & Approved \\
\hline & Reduce audit costs & 5.20 & 0.65 & Approved \\
\hline & $\begin{array}{l}\text { Management } \\
\text { effectiveness in } \\
\text { controlling unexpected } \\
\text { changes in tax rates }\end{array}$ & 5.20 & 0.65 & Approved \\
\hline & $\begin{array}{l}\text { The dynamics of the } \\
\begin{array}{l}\text { company's } \\
\text { strategies }\end{array} \\
\end{array}$ & 5.50 & 0.85 & Approved \\
\hline & $\begin{array}{ll}\text { Reduce } & \text { financial } \\
\text { constraints } & \\
\end{array}$ & 6 & 0.90 & Approved \\
\hline
\end{tabular}


Based on the outcome of the second round of the Delphi analysis, it was decided that all 15 approved and incorporated measures from the first round of the Delphi analysis were also approved in the second round.

\section{Total Interpretive Structural Modeling Results}

The third section of the research starts with detailed Total Interpretive Structural Modeling (TISM) after Delphi validation. The panel members participated in this section and submitted the overview section's scores to the matrix questionnaires. Because TISM is an expanded example of ISM, the augmented method for TISM as a more detailed tool can evaluate the layers of interactive interaction between study indicators. To start this analysis, it is important to encrypt the accepted indicators at the Delphi analysis level.

Table 8. Abbreviated coding of approved propositions

\begin{tabular}{|l|c|}
\hline Index & Acronym \\
\hline Greater dynamics of company value based on tax transparency & C1 \\
\hline Increasing the level of stakeholder decision-making values & $\mathrm{C} 2$ \\
\hline Promote trust by convincing sustainable tax reporting & $\mathrm{C} 3$ \\
\hline Reduce institutional tax risk in the company & $\mathrm{C} 4$ \\
\hline Reduction of profit before tax & $\mathrm{C} 5$ \\
\hline Sustainability in profit after tax & $\mathrm{C} 6$ \\
\hline Ability to predict future cash flows & $\mathrm{C} 7$ \\
\hline Improving the level of tax exemptions and reducing financial costs & $\mathrm{C} 8$ \\
\hline $\begin{array}{l}\text { Increasing the level of disclosure of economic performance in line with the GRI } \\
\text { standard }\end{array}$ & $\mathrm{C} 9$ \\
\hline The strategic fit between tax depreciation and company value & $\mathrm{C} 10$ \\
\hline Tax rate uniformity & $\mathrm{C} 11$ \\
\hline Reduce audit costs & $\mathrm{C} 12$ \\
\hline Management effectiveness in controlling unexpected changes in tax rates & $\mathrm{C} 13$ \\
\hline The dynamics of the company's business strategies & $\mathrm{C} 14$ \\
\hline Reduce financial constraints & $\mathrm{C} 15$ \\
\hline
\end{tabular}

As shown in Table 8, the metrics accepted by the experts are abbreviated to construct their systemic interaction matrix. To enhance the interpretive structural analysis for a total interpretive structural analysis, any pairwise distinction must be fully understood by addressing the interpretive query referred to in the preceding stage. For pairwise comparisons, the I index is compared in pairs to all elements from $(i+1)$ to nth. Thus, the table below gives two responses for " $\mathrm{C}$ " or " $\mathrm{N}$ " for each index's association, and the positive response shows the diagonal and indirect relationship of the variables. But if the answer is "N," the participants can comment on the variable pair. 
Table 9. Pairwise comparison between propositions based on the form of the matrix

\begin{tabular}{|c|c|c|c|}
\hline N. & $\begin{array}{l}\text { Pairwise } \\
\text { comparison }\end{array}$ & Yes/No & Influence description \\
\hline \multicolumn{4}{|c|}{$\square$ C1Higher dynamics of company value based on tax transparency } \\
\hline 1 & $\mathrm{C} 1-\mathrm{C} 2$ & $\begin{array}{l}\text { Yes } \otimes \\
\text { No } \square\end{array}$ & $\begin{array}{l}\text { More dynamic value of the company, a factor to increase the } \\
\text { level of investment values of stakeholders }\end{array}$ \\
\hline 2 & $\mathrm{C} 2-\mathrm{C} 1$ & $\begin{array}{l}\text { Yes } \square \\
\text { No } \square\end{array}$ & \\
\hline 3 & $\mathrm{C} 1-\mathrm{C} 3$ & $\begin{array}{l}\text { Yes } \bigotimes \\
\text { No } \square\end{array}$ & $\begin{array}{l}\text { More dynamic value of the company, a factor to enhance trust } \\
\text { due to the persuasion of tax reporting }\end{array}$ \\
\hline 4 & $\mathrm{C} 3-\mathrm{C} 1$ & $\begin{array}{l}\text { Yes } \square \\
\text { No } \bigotimes\end{array}$ & \\
\hline 5 & $\mathrm{C} 1-\mathrm{C} 4$ & $\begin{array}{l}\text { Yes } \bigotimes \\
\text { No } \square\end{array}$ & $\begin{array}{l}\text { More dynamic value of the company is a factor to reduce the } \\
\text { institutional tax risk in the company }\end{array}$ \\
\hline 6 & $\mathrm{C} 4-\mathrm{C} 1$ & $\begin{array}{l}\text { Yes } \bigotimes \\
\text { No } \square\end{array}$ & $\begin{array}{l}\text { Reducing institutionalized tax risk by raising the value of the } \\
\text { company in a competitive environment }\end{array}$ \\
\hline 7 & $\mathrm{C} 1-\mathrm{C} 5$ & $\begin{array}{l}\text { Yes } \bigotimes \\
\text { No } \square\end{array}$ & $\begin{array}{l}\text { Company value dynamics are a stimulus for lower pre-tax } \\
\text { profits }\end{array}$ \\
\hline 8 & $\mathrm{C} 5-\mathrm{C} 1$ & $\begin{array}{l}\text { Yes } \square \\
\text { No } \bigotimes\end{array}$ & $\begin{array}{l}\text { Company value dynamics are a driver for profit stability after } \\
\text { tax }\end{array}$ \\
\hline 9 & $\mathrm{C} 1-\mathrm{C} 6$ & $\begin{array}{l}\text { Yes } \bigotimes \\
\text { No } \square\end{array}$ & \\
\hline 10 & $\mathrm{C} 6-\mathrm{C} 1$ & $\begin{array}{l}\text { Yes } \square \\
\text { No } \unrhd\end{array}$ & \\
\hline 11 & $\mathrm{C} 1-\mathrm{C} 7$ & $\begin{array}{l}\text { Yes } \bigotimes \\
\text { No } \square\end{array}$ & $\begin{array}{l}\text { Company value dynamics are a stimulus for predicting future } \\
\text { cash flows }\end{array}$ \\
\hline 12 & $\mathrm{C} 7-\mathrm{C} 1$ & $\begin{array}{l}\text { Yes } \square \\
\text { No } \bigotimes\end{array}$ & \\
\hline 13 & $\mathrm{C} 1-\mathrm{C} 8$ & $\begin{array}{l}\text { Yes } \bigotimes \\
\text { No } \square\end{array}$ & $\begin{array}{l}\text { The dynamics of the value of the company is a stimulus to } \\
\text { improve the level of tax exemption }\end{array}$ \\
\hline 14 & $\mathrm{C} 8-\mathrm{C} 1$ & $\begin{array}{l}\text { Yes } \bigotimes \\
\text { No } \square\end{array}$ & $\begin{array}{l}\text { Improving the level of tax exemptions and reducing costs is a } \\
\text { reason for the more dynamic value of the company }\end{array}$ \\
\hline 15 & $\mathrm{C} 1-\mathrm{C} 9$ & $\begin{array}{l}\text { Yes } \square \\
\text { No } \bigotimes\end{array}$ & \\
\hline 16 & $\mathrm{C} 9-\mathrm{C} 1$ & $\begin{array}{l}\text { Yes } \square \\
\text { No } \bigotimes\end{array}$ & \\
\hline 17 & $\mathrm{C} 1-\mathrm{C} 10$ & $\begin{array}{l}\text { Yes } \square \\
\text { No } \unrhd\end{array}$ & \\
\hline 18 & $\mathrm{C} 10-\mathrm{C} 1$ & $\begin{array}{l}\text { Yes } \square \\
\text { No } \unrhd\end{array}$ & \\
\hline 19 & $\mathrm{C} 1-\mathrm{C} 11$ & $\begin{array}{l}\text { Yes } \bigotimes \\
\text { No } \square\end{array}$ & Company value dynamics are a factor for tax rate uniformity \\
\hline 20 & $\mathrm{C} 11-\mathrm{C} 1$ & $\begin{array}{l}\text { Yes } \square \\
\text { No } 囚\end{array}$ & \\
\hline 21 & $\mathrm{C} 1-\mathrm{C} 12$ & Yes $\bigotimes$ & Company value dynamics are a factor in reducing audit costs \\
\hline
\end{tabular}


Iranian Journal of Finance, 2020, Vol. 4, No. 4 (Abedi, H.)

\begin{tabular}{|c|c|c|c|}
\hline & & No $\square$ & \\
\hline 22 & $\mathrm{C} 12-\mathrm{C} 1$ & $\begin{array}{l}\text { Yes } \square \\
\text { No } \bigotimes\end{array}$ & \\
\hline 23 & $\mathrm{C} 1-\mathrm{C} 13$ & $\begin{array}{l}\text { Yes } \bigotimes \\
\text { No } \square\end{array}$ & $\begin{array}{l}\text { Company value dynamics are a factor for managerial } \\
\text { effectiveness }\end{array}$ \\
\hline 24 & $\mathrm{C} 13-\mathrm{C} 1$ & $\begin{array}{l}\text { Yes } \square \\
\text { No } \square\end{array}$ & \\
\hline 25 & $\mathrm{C} 1-\mathrm{C} 14$ & $\begin{array}{l}\text { Yes } \bigotimes \\
\text { No } \square\end{array}$ & $\begin{array}{l}\text { Company value dynamics A factor in the dynamics of corporate } \\
\text { strategies }\end{array}$ \\
\hline 26 & $\mathrm{C} 14-\mathrm{C} 1$ & $\begin{array}{l}\text { Yes } \square \\
\text { No } \square\end{array}$ & \\
\hline 27 & $\mathrm{C} 1-\mathrm{C} 15$ & $\begin{array}{l}\text { Yes } \bigotimes \\
\text { No } \square\end{array}$ & $\begin{array}{l}\text { Company value dynamics are a factor in reducing financial } \\
\text { constraints }\end{array}$ \\
\hline 28 & $\mathrm{C} 15-\mathrm{C} 1$ & $\begin{array}{l}\text { Yes } \square \\
\text { No } \bigotimes\end{array}$ & \\
\hline
\end{tabular}

To form the "SSIM" hierarchical self-interaction matrix, pairwise analyses of financial output deficiencies are shown in Table 11. For pairwise comparisons, the I index was contrasted in pairs to all elements from $(i+1) n$ to $\mathrm{n}$. For each relation, the answer is " $\mathrm{C}$ " or "N," and the explanation is given in the event of a positive answer. In this case, the interpretive logic of pair relations is provided in the context of a simple empirical understanding of logic. In this step, the relationship is entered as an accomplishment matrix in the form of "1" or " 0 ," as shown in Table 10. According to Table 9, the cells with the "Yes" option are set to 1 , and the cells with the "No" option to 0 . This matrix is obtained by transforming the structural relationship matrix into a negative and a single binary matrix.

Table 10. Accessibility matrix

\begin{tabular}{|l|l|l|l|l|l|l|l|l|l|l|l|l|l|l|l|}
\hline & C1 & C2 & C3 & C4 & C5 & C6 & C7 & C8 & C9 & C10 & C11 & C12 & C13 & C14 & C15 \\
\hline C1 & 1 & 1 & 1 & 0 & 0 & 1 & 1 & 0 & 0 & 0 & 1 & 1 & 1 & 1 & 1 \\
\hline C2 & 0 & 1 & 1 & 1 & 0 & 1 & 1 & 1 & 0 & 0 & 0 & 0 & 0 & 0 & 1 \\
\hline C3 & 0 & 0 & 1 & 0 & 0 & 0 & 1 & 0 & 0 & 0 & 0 & 0 & 0 & 0 & 0 \\
\hline C4 & 0 & 0 & 0 & 1 & 0 & 0 & 1 & 0 & 0 & 0 & 0 & 0 & 0 & 0 & 1 \\
\hline C5 & 0 & 1 & 1 & 1 & 1 & 1 & 1 & 1 & 0 & 0 & 0 & 0 & 0 & 0 & 1 \\
\hline C6 & 0 & 0 & 1 & 1 & 0 & 1 & 1 & 1 & 0 & 0 & 0 & 0 & 0 & 0 & 0 \\
\hline C7 & 0 & 0 & 0 & 0 & 0 & 0 & 1 & 0 & 0 & 0 & 0 & 0 & 0 & 0 & 1 \\
\hline C8 & 0 & 0 & 0 & 0 & 0 & 0 & 1 & 1 & 0 & 0 & 0 & 0 & 0 & 0 & 1 \\
\hline C9 & 0 & 0 & 0 & 1 & 1 & 0 & 1 & 1 & 1 & 0 & 0 & 0 & 0 & 0 & 1 \\
\hline C10 & 0 & 0 & 0 & 1 & 1 & 0 & 1 & 0 & 0 & 1 & 0 & 0 & 0 & 0 & 1 \\
\hline C11 & 0 & 1 & 1 & 1 & 0 & 1 & 1 & 1 & 0 & 0 & 1 & 0 & 0 & 0 & 1 \\
\hline C12 & 0 & 1 & 1 & 1 & 0 & 1 & 1 & 1 & 0 & 0 & 0 & 1 & 0 & 0 & 1 \\
\hline C13 & 0 & 0 & 1 & 1 & 0 & 1 & 1 & 0 & 0 & 0 & 0 & 0 & 1 & 0 & 1 \\
\hline C14 & 0 & 0 & 0 & 0 & 0 & 0 & 1 & 0 & 0 & 0 & 0 & 0 & 0 & 1 & 0 \\
\hline C15 & 0 & 0 & 0 & 0 & 0 & 0 & 1 & 0 & 0 & 0 & 0 & 0 & 0 & 0 & 1 \\
\hline
\end{tabular}


Then, at this step, points are built based on the indices' interaction to form the interaction of the accessibility matrix.

Table 11. Accessibility matrix in terms of the rate of transferability of the relationship between propositions

\begin{tabular}{|l|l|l|l|l|l|l|l|l|l|l|l|l|l|l|l|}
\hline & C1 & C2 & C3 & C4 & C5 & C6 & C7 & C8 & C9 & C10 & C11 & C12 & C13 & C14 & C15 \\
\hline C1 & 1 & 1 & 1 & $1^{*}$ & 0 & 1 & 1 & $1^{*}$ & 0 & 0 & 1 & 1 & 1 & 1 & 1 \\
\hline C2 & 0 & 1 & 1 & 1 & 0 & 1 & 1 & 1 & 0 & 0 & 0 & 0 & 0 & 0 & 1 \\
\hline C3 & 0 & 0 & 1 & 0 & 0 & 0 & 1 & 0 & 0 & 0 & 0 & 0 & 0 & 0 & 0 \\
\hline C4 & 0 & 0 & 0 & 1 & 0 & 0 & 1 & 0 & 0 & 0 & 0 & 0 & 0 & 0 & 1 \\
\hline C5 & 0 & 1 & 1 & 1 & 1 & 1 & 1 & 1 & 0 & 0 & 0 & 0 & 0 & 0 & 1 \\
\hline C6 & 0 & 0 & 1 & 1 & 0 & 1 & 1 & 1 & 0 & 0 & 0 & 0 & 0 & 0 & 0 \\
\hline C7 & 0 & 0 & 0 & 0 & 0 & 0 & 1 & 0 & 0 & 0 & 0 & 0 & 0 & 0 & 1 \\
\hline C8 & 0 & 0 & 0 & 0 & 0 & 0 & 1 & 1 & 0 & 0 & 0 & 0 & 0 & 0 & 1 \\
\hline C9 & 0 & $1^{*}$ & $1^{*}$ & 1 & 1 & $1^{*}$ & 1 & 1 & 1 & 0 & 0 & 0 & 0 & 0 & 1 \\
\hline C10 & 0 & $1^{*}$ & $1^{*}$ & 1 & 1 & $1^{*}$ & 1 & $1^{*}$ & 0 & 1 & 0 & 0 & 0 & 0 & 1 \\
\hline C11 & 0 & 1 & 1 & 1 & 0 & 1 & 1 & 1 & 0 & 0 & 1 & 0 & 0 & 0 & 1 \\
\hline C12 & 0 & 1 & 1 & 1 & 0 & 1 & 1 & 1 & 0 & 0 & 0 & 1 & 0 & 0 & 1 \\
\hline C13 & 0 & 0 & 0 & 1 & 0 & 1 & 1 & $1^{*}$ & 0 & 0 & 0 & 0 & 1 & 0 & 1 \\
\hline C14 & 0 & 0 & 0 & 0 & 0 & 0 & 1 & 0 & 0 & 0 & 0 & 0 & 0 & 1 & 0 \\
\hline C15 & 0 & 0 & 0 & 0 & 0 & 0 & 1 & 0 & 0 & 0 & 0 & 0 & 0 & 0 & 1 \\
\hline
\end{tabular}

As shown in the table above, the pattern symbols allocated based on the fashion index have been translated to 0,1 , and $* 1$ point, according to the mathematical relationship's meaning to the numbers in the previous table. In the table below, define the penetration power ( 1 and $*$ points from the row) and the dependence power ( 1 and $* 1$ point from the column):

Table 12. Separation of influence and dependence forces

\begin{tabular}{|c|c|c|c|c|c|c|c|c|c|c|c|c|c|c|c|}
\hline Criteria & C1 & C2 & C3 & C4 & C5 & C6 & C7 & C8 & C9 & C10 & C11 & C12 & C13 & C14 & C15 \\
\hline $\begin{array}{c}\text { Influence } \\
\text { force }\end{array}$ & 12 & 7 & 2 & 3 & 8 & 5 & 2 & 3 & 9 & 9 & 8 & 8 & 6 & 2 & 12 \\
\hline $\begin{array}{c}\text { Dependenc } \\
\text { e force }\end{array}$ & 1 & 7 & 9 & 10 & 3 & 9 & 15 & 10 & 1 & 1 & 2 & 2 & 2 & 2 & 12 \\
\hline
\end{tabular}

First, to evaluate the relationship between ideas, we must define the output set, the input set, and the popular elements. The score level and the variables' priority shall be determined by each variable's achievement and prerequisite set. The reference collection of each variable contains the variables that can be accessed by this variable, and the preset contains the variables from which this variable can be accessed. The subscriptions of the access settings and the specifications of all variables are then calculated. If the access set is the same as the subscription set of that factor(s), it is assumed to be the priority 
amount. The surface corresponds to the layers of the final model. The previous levels must be separated from the matrix to achieve additional levels, and the procedure must be replicated. If the levels have been calculated again, organize the obtained matrix in the thresholds, the current matrix is called the conical matrix. In this step, each variable's output and input sets are obtained using the final access matrix.

Output and input sets for variables are defined as follows. The performance set for a specific dimension/component is the variable itself and other variables influenced by it. In other words, the variables that can be accessed by that variable. The input set for each variable contains the variable itself and the other variables that influence it. Finally, the standard elements apply to the output set's common dimensions and variables' input in the complete interpretive structural modeling (TISM) as a high-level variable. In other words, these variables are not useful when generating any other variable. After deciding the output elements, input elements, and common elements, the index that the output elements and common elements have the same shall be defined as the first stage and the least effective indicators. After this level has been defined, i.e., the least effective indicators, we delete this index and analyze the same input indicators and common elements and pick it as the next step. This procedure is replicated until the components at all stages of the device are established.

Table 13. Set of the input/output indices and the common elements of the propositions

\begin{tabular}{|c|c|c|c|c|}
\hline Level & Common elements & Input index & Output index & Acronym \\
\hline $7^{\text {th }}$ & $1,2,3,4,6,7,8,11,12,13$, & 1 & 1 & $\mathrm{C} 1$ \\
\hline $\mathbf{5}^{\text {th }}$ & $2,3,4,6,7,8,15$ & $1,2,5,910,11,12$ & 2 & $\mathrm{C} 2$ \\
\hline $\mathbf{2}^{\text {nd }}$ & 3,7 & & 3 & $\mathrm{C} 3$ \\
\hline $\mathbf{3}^{\text {rd }}$ & $4,7,15$ & $1,2,3,5,6,9,10,11,12,13$ & 4 & $\mathrm{C} 4$ \\
\hline $\mathbf{6}^{\text {th }}$ & $2,3,4,5,6,7,8,15$ & $5,9,10$ & 5 & $\mathrm{C} 5$ \\
\hline $\mathbf{4}^{\text {th }}$ & $3,4,6,7,8,15$ & $1,2,5,6,9,10,11,12,13$ & 6 & $\mathrm{C} 6$ \\
\hline $\mathbf{1}^{\text {st }}$ & 7 & $1,2,3,4,5,6,7,8,9,10,11$, & 7 & $\mathrm{C} 7$ \\
\hline $\mathbf{3}^{\text {rd }}$ & $7,8,15$ & $12,13,14,15$ & 8 & $\mathrm{C} 8$ \\
\hline $\mathbf{7}^{\text {th }}$ & $2,3,4,5,6,7,8,9,15$ & $1,2,5,6,8,9,10,11,12,13$ & 9 & $\mathrm{C} 9$ \\
\hline $\mathbf{7}^{\text {th }}$ & $2,3,4,5,6,7,8,9,15$ & 9 & 10 & $\mathrm{C} 10$ \\
\hline $\mathbf{6}^{\text {th }}$ & $2,3,4,6,7,8,11,15$ & 10 & 11 & $\mathrm{C} 11$ \\
\hline $\mathbf{6}^{\text {th }}$ & $2,3,4,6,7,8,12,15$ & 1,11 & 12 & $\mathrm{C} 12$ \\
\hline $\mathbf{5}^{\text {th }}$ & $3,4,6,7,8,13,15$ & 1,12 & 13 & $\mathrm{C} 13$ \\
\hline $\mathbf{2}^{\text {nd }}$ & 7,14 & 1,13 & 14 & $\mathrm{C} 14$ \\
\hline $\mathbf{2}^{\text {nd }}$ & 7,15 & $1,2,4,5,6,8,9,10,11,12$, & 15 & $\mathrm{C} 15$ \\
\hline
\end{tabular}


As shown in Table (13), the first and least powerful predictor is the capacity to forecast potential cash flows (C7) to indicate the external knowledge setting's components. However, the most powerful predictor of the production of tax stability under information system circumstances, metrics, a greater dynamics of business valuation dependent on tax transparency $(\mathrm{C} 1)$ as a predictor of external information environment components and an-level of disclosure of economic output in line with GRI (C9) and a strategic convergence with tax minimization. Organizational importance $(\mathrm{C} 10)$ as a measure of the components of the internal information setting. Accordingly, similar to the study, Figure (5) displays the layered model of proposals from the most effective to the least effective.

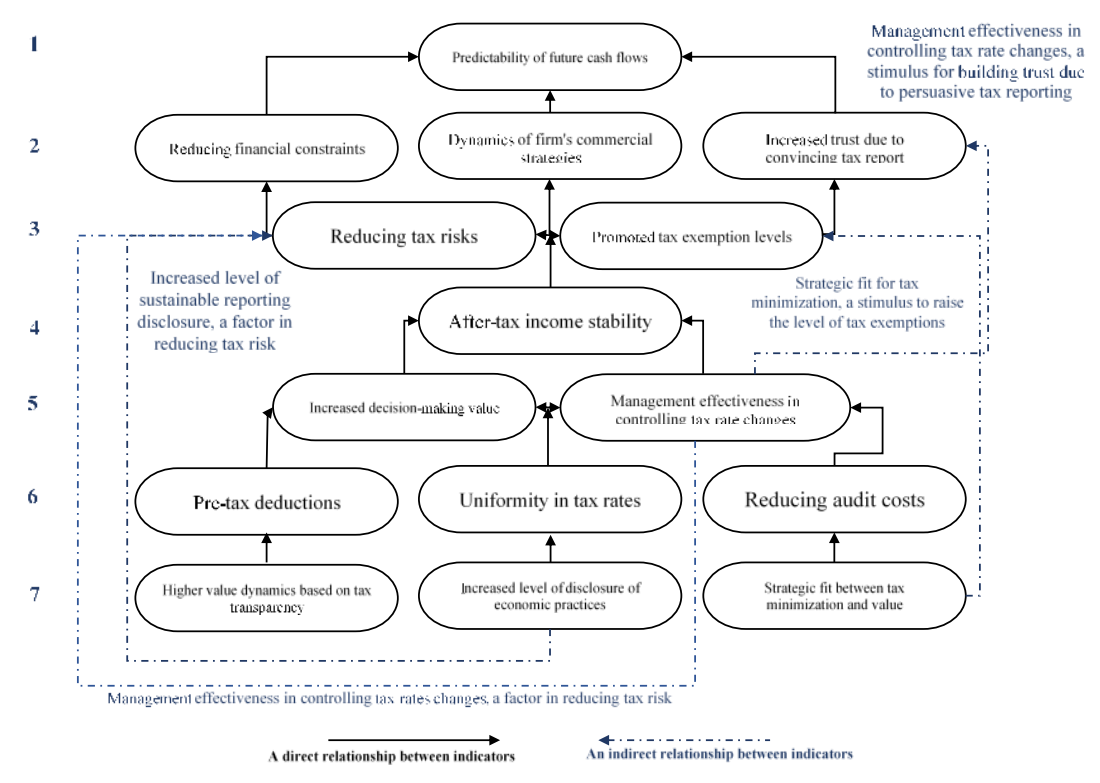

Figure 2: Design of a stratified model of tax sustainability development indices under the conditions of the information environment

\section{Conclusion and Discussion}

This analysis aims to provide a model of sustainable tax production functions within the Tehran Stock Exchange firms' knowledge ecosystem. Based on the findings of the layered model, a higher value dynamic based on tax transparency was established as a predictor of the success aspect of the competitive information environment, suggesting that if information functions step towards increasing knowledge and information asymmetries, while at the 
same time developing the valuation of the business based on tax transparency. Companies who show this degree of sustainable revenue growth capacity, both in terms of transparency of financial and tax results and the production of committed tax activity, have more diverse capacities to improve competitive success due to improved business valuation and increased market share. On the other hand, based on the index of growing the level of transparency of economic results in the form of a GRI report as a foundation for sustainability reporting in the form of corporate internal information functions, it indicates that an organization based on social responsibility principles has an economic performance at the business level.

At the social level, accountability can be created. Due to reliable tax functions, it will boost the organization's rank and efficiency in the stock market and enhance the firm's enhanced market interest and trust. At this stage, the strategic balance between the tax minimization and the company's valuation is also an indication of the company's internal knowledge setting's activities, enhancing the organization's degree of operating stability. Tax minimization is a tax evasion solution that can negatively affect the company's activities due to the accumulation of negative news and information if it is not in line with the policies. As a result, with the introduction of sustainable tax functions, a strategic balance is established between tax minimization and business valuation. With a rise in company value, company tax minimization is handled in proportion to its face and prestige.

In other words, based on the functions of sustainable tax development, the company seeks to be more committed to creating fixed tax procedures in a dynamic information environment by lowering the effective tax rate in the long run, while at the same time controlling the tax costs, to maintain the company's value on the capital market. At the second stage of the successful prioritization of sustainable tax growth functions, three measures of reducing benefit before tax is included; uniformity of tax rates and decreased audit costs. Reducing pre-tax income and stabilizing and reducing uncertainty results from the company's fiscal flexibility in a complex knowledge setting that minimizes effective tax rates and decreases tax expenses, including tax fines and associated funding costs. Continuity of benefit reducers will help increase the company's productivity level in the long run and increase the level of trust and interest in the company's capital market elements. It has also been found that the tax uniformity index is also located at this level. Tax uniformity is a modern approach to successful tax planning that focuses on ensuring consistent long-term implications for tax stability and demonstrates little heterogeneity in predictable tax consequences over a long period. In this regard, it should be 
noted that tax uniformity varies from tax minimization by tax evasion and focuses on developing long-term incorporation into the consistent functions of taxation and its declaration in the form of business reports. Finally, at this stage, it was observed that the reduction in audit costs was due to the development in clear operational standards of accounting of the company's financial statements, which could improve the profitability of the firm along with other tax costs and optimize shareholder capital as an efficient approach to financial management.

At the third stage of the model, it was observed that there was a rise in the degree of stakeholder decision-making and managerial efficacy in managing unforeseen shifts in tax rates. Increasing the amount of stakeholder investment values would be generated by knowledge symmetry and the development of an effective tax information setting. It will raise the stakeholder's degree of happiness by improving the strength of their contributions and generating more dynamism in the company's investment functions. On the other hand, management efficacy in managing tax rate adjustments is associated with tax uniformity, which provides a kind of corporate tax management which can boost the relationship between the corporation which creditors by increasing tax deductions, so it lowers tax costs and improves the productivity of the company's income and enhances co-operation. Finally, at the highest level of the layered model and the least successful one has been established, the ability to forecast cash flows is a consequence of the roles of sustainable tax growth, which implies that while the ability to predict future cash flows due to the company's tax stability under the Knowledge Environment is an essential and competitive ability to improve competitiveness. However, it has a low effect because, due to economic difficulties, forecasting as an acquisition criterion, at least in our stock market's economic environment, combines with a lot of volatility.

This would not make the company's operational or free cash flow forecasting operations very straightforward. These findings indicate that improving fiscal stabilization functions under the corporate knowledge environment's constraints are seen as an internal advantage as an effective basis of operations and an external advantage as a strategic base in the stock market that can improve demand growth. Sustainable advertising in all facets of society, the environment, particularly the economy, and maintaining a balance between tax minimization and the company's socially acceptable ideals and increasing the degree of confidence and trust in the company. Conceptual findings for Wilde and Wilson's (2018) research; Jenter, Matsunaga, and Matsunaga (2017); Shanti and Tang (2017) and McGuire, Newman, and Omer 
(2013). The following recommendations are given based on the findings obtained:

Based on the results obtained, it is suggested, Improving the quality of firms' information environment requires adjusting regulatory methods in specialized formats such as finance and taxation; in other words, regulatory authorities and organizations may, by specialized committees, obtain adequate knowledge of the reality of the financial market under economic sanctions to further improve the level of financial and organizational activities of businesses. The tax administration, as a beneficiary institution, should be compliant with government tax policies and, at the same time, increase the preparation of taxpayers at the macro level, such as stock market firms, to establish tax account to build competitive tax functions and to enact resolutions to enforce them, acting in compliance with the Established Tax Framework. It also suggested to shareholders and investors to view the Sustainable Reporting Success Score efficiency of their acquisitions as a favorable capital market foundation when firms with higher reporting quality ratings have greater prices than their potential performance predictions for improved investment. Finally, it is suggested that businesses leverage existing potentials in tax stabilization roles to engage more efficiently with government and stock market components, focused on developing standardized tax policies, on achieving a more dynamic degree of attracting shareholders and investors in the capital market.

Funding: This research received no external funding.

\section{References}

Abernathy, J, A., Kubick, Th, R., Masli, A. (2016). General Counsel Prominence and Corporate Tax Policy. The Journal of the American Taxation Association, 38(1): 39-56 .https://doi.org/10.2308/atax-51258

Akerlof, G. A. (1970). The market for "lemons": Quality uncertainty and the market mechanism. The Quarterly Journal of Economics, 84(3), 488-500.

Beck, P. J., Davis, J. S., Jung, W, O., (1996). Tax advice and reporting under uncertainty: theory and experimental evidence, Contemporary Accounting Research, 13(1): 49-80.

Beyer, A., Cohen, D. A., Lys, T. Z., \& Walther, B. (2010). The financial reporting environment: Review of the recent literature. Journal of Accounting and Economics, 50(2-3): 296-343. https://doi.org/10.1016/j.jacceco.2010.10.003 
Chen, C, W., Hepfer, B, F., Quinn, Ph, J., Wilson, R, J. (2018). The effect of tax-motivated income shifting on information asymmetry, Review of Accounting Studies, 23(3): 958-100. https://doi.org/10.1007/s11142-018-9439-1

David, A., Wilson, R, J., Kaishu, W. (2019) Tax Uncertainty and Incremental Tax Avoidance. The Accounting Review, 94(2): 229-247. https://doi.org/10.2308/accr$\underline{52194}$

Deloitte, L, L, P. (2013). Responsible Tax: Sustainable Tax Strategy.

Desai, M., Dharmapala, D. (2009). Earnings Management, Corporate Tax Shelters , and Book-Tax Alignment, National Tax Journal, 62(1): 213-239.

Diaz-Balteiro, Gonzalez-Pachon, J., Romero, C. (2017). Measuring systems sustainability with multi-criteria methods: A critical review, European Journal of Operational Research, 258(2): 607-616. https://doi.org/10.1016/j.ejor.2016.08.075

Dyreng, S, D., Hanlon, M., Maydew, E, L. (2019). When Does Tax Avoidance Result in Tax Uncertainty? The Accounting Review, 94(2): 179-203. https://doi.org/10.2308/accr-52198

Dyreng, S., Hanlon, M., Maydew, E. (2014). Rolling the Dice: When does Tax Avoidance Result in Tax Uncertainty? Working paper, Duke University, Massachusetts Institute of Technology, and The University of North Carolina.

Fakhari H, Rezaei Pitenoei Y. Explaining a Model for Measuring Corporate Information Environment. quarterly financial accounting journal. 2017; 9 (33) :121147

Gallemore, J., Labro, E. (2015). The importance of the internal information environment for tax avoidance, Journal of Accounting and Economics, 60(1): 149167. https://doi.org/10.1016/j.jacceco.2014.09.005

Guenther, D, A., Matsunaga, S, R., Williams, B, M. (2017). Is Tax Avoidance Related to Firm Risk? The Accounting Review, 92(1):115-136. https://doi.org/10.2308/accr-51408

Hamilton, R., Stekelberg, J. (2017). The Effect of High-Quality Information Technology on Corporate Tax Avoidance and Tax Risk, Journal of Information Systems, 31(2): 83-106. https://doi.org/10.2308/isys-51482

Healy, P. and Palepu, K. G., (1993). The Effect of Firms' Financial Disclosure Policies on Stock Prices, Accounting Horizons, 7(3): 1-11.

Heidarzadeh Hanzaei, A., Barati, L. (2019). Information Environment and Earnings Management in Companies to Dual Holdings. Journal of Investment Knowledge, 8(29), 215-332.

Hoffman, W. H. (1961). The theory of tax planning. The Accounting Review, 36(2): 274-281 
Hogsden J. (2018). The Contemporary Corporate Tax Strategy Environment, Contemporary Issues in Accounting, 22(4): 85-104. https://doi.org/10.1007/978-3319-91113-7_5

Hutchens, M., Rego, S, O. (2015). Tax Risk and the Cost of Equity Capital . Working paper, Indiana University.

Kaffashpour Yazdi, M., Taftiyan, A., Moeinaddin, M. (2019). Investigating the Effect of Information Environment on the Relationship between Management Forecast Error and Idiosyncratic Risk in Companies Accepted in Tehran Stock Exchange. Management Accounting, 12(41), 151-169.

Leece, R. D., White, T, P. (2017). The effects of firms' information environment on analysts' herding behavior, Review of Quantitative Finance and Accounting, 48(2): 503-525. https://doi.org/10.1007/s11156-016-0559-z

Malaquias, R., Junior, D. (2019). Strategy, tax planning and liquidity constraints in investment funds, Journal of Economic Studies, 46(4):842-857. https://doi.org/10.1108/JES-11-2017-0334

McGuire, S., Neuman, S., Omer, T. (2013). Sustainable Tax Strategies and Earnings Persistence. Working paper, Texas A\&M University and the University of Nebraska-Lincoln.

Mgammal, M. (2019). Corporate tax planning and corporate tax disclosure, Meditari Accountancy Research, https://doi.org/10.1108/MEDAR-11-2018-0390

Papadopoulou P., Hristu-Varsakelis D. (2019). Tax Evasion as an Optimal Solution to a Partially Observable Markov Decision Process. Approximation and Optimization, 145(11): 219-237. https://doi.org/10.1007/978-3-030-12767-1_11

Phillips, J.D (2003). Corporate Tax-planning Effectiveness: the Role of Compensation based Incentives, The Accounting Review, 78(3): 847-874. https://doi.org/10.2308/accr.2003.78.3.847

Ppourhaidari, O., Shafiei Hemmatabad, H. (2013). The Impact of Corporate Tax Rate Change for Earnings Management: The Case Study Reform Taxation Act in 1380. Applied Research in Financial Reporting, 2(1), 25-44.

Sadeghi, S., Ranjpor, R., Bagherzadeh Azar, F., Mousavi, S. (2016). The Effects of Tax Policies on Financial Markets Development. Iranian Journal of Economic Research, 20(65), 37-61.

Sari M, Etemadi H, Sepasi S. The Importance of the Internal Information Environment Quality for Tax Risk Reduction. IQBQ. 2019; 23 (2) :1-27

Shanthi, R., Tong, P, K. (2017). The Persistent Reduction in Poverty from Filing a Tax Return, American Economic Journal: Economic Policy, 9(4):367-94.

Tanyi, P., Burton, H. (2019). Financial Statement Aggressiveness Related to Tax 
Accounts and Tax-Related Accounting Misstatements, Accounting and the Public, https://doi.org/10.2308/apin-52544

Wang, T. (2019). Product market competition and efficiency of corporate tax management, Asian Review of Accounting, 27(2): 247-272. https://doi.org/10.1108/ARA-07-2018-0136

Wilde, J, H., Wilson, R, J. (2018). Perspectives on Corporate Tax Planning: Observations from the Past Decade. The Journal of the American Taxation Association, 40(2): 63-81 .https://doi.org/10.2308/atax-51993

Bibliographic information of this paper for citing:

Abedi, Hasan \& Abdoli, Mohammad Reza (2020). Model of Sustainable Tax Development Practices under Information Environment by Total Interpretive/Structural Model (TISM). Iranian Journal of Finance, 4(4), 1-27.

Copyright ( 2020, Hasan Abedi and Mohammad Reza Abdoli 